Experimental Studies 


\title{
Low Levels of Microsatellite Instability at Simple Repeated Sequences Commonly Occur in Human Hepatocellular Carcinoma
}

\author{
CLAIRE GOUMARD $^{1}$, CHRISTELE DESBOIS-MOUTHON ${ }^{1}$, DOMINIQUE WENDUM ${ }^{1,2}$, \\ CLAIRE CALMEL ${ }^{1}$, FATIHA MERABTENE ${ }^{1,3}$, OLIVIER SCATTON ${ }^{1,4^{*}}$ and FRANÇOISE PRAZ ${ }^{1}$ \\ ${ }^{1}$ Sorbonne Universités, UPMC Univ Paris 06, INSERM, CNRS, \\ Centre de Recherche Saint-Antoine (CRSA), Paris, France; \\ ${ }^{2}$ APHP, Hôpital Saint-Antoine, Service d'Anatomie Pathologique, Paris, France; \\ ${ }^{3}$ Plateforme d'Histomorphologie Saint-Antoine, UMS 30, Paris, France; \\ ${ }^{4}$ APHP, Hôpital Saint-Antoine, Service de Chirurgie Hépatobiliaire, Paris, France
}

\begin{abstract}
Background/Aim: The aim of this study was to assess the incidence of MSI in a large series of human hepatocellular carcinomas (HCC) with various etiologies. Materials and Methods: The MSI status was determined by polymerase chain reaction (PCR) using 5 mononucleotide and 13 CAn dinucleotide repeats. Results: None of the 122 HCC samples displayed an MSI-High phenotype, as defined by the presence of alterations at more than $30 \%$ of the microsatellite markers analyzed. Yet, limited microsatellite instability consisting in the insertion or deletion of a few repeat motifs was detected in 32 tumor samples (26.2\%), regardless of the etiology of the underlying liver disease. MSI tended to be higher in patients with cirrhosis ( $p=0.051)$, possibly reflecting an impact of the inflammatory context in this process. Conclusion: Based on a large series of HCC with various etiologies, our study allowed us to definitely conclude that MSI is not a hallmark of HCC.
\end{abstract}

Hepatocellular carcinoma (HCC) is the fifth leading cause of cancer worldwide in men and the seventh in women. Major risk factors for $\mathrm{HCC}$ include infection with hepatitis $\mathrm{B}$ or $\mathrm{C}$ viruses (HBV or $\mathrm{HCV}$ ), alcohol-induced liver disease. The

This article is freely accessible online.

*Current address: APHP, Hôpital La Pitié-Salpetriere, Service de Chirurgie Hepatobiliaire et Transplantation, Paris, France.

Correspondence to: Françoise Praz, Centre de Recherche SaintAntoine, INSERM - UPMC UMR_S938, 184 rue du Faubourg Saint-Antoine, 75012 Paris, France. E-mail: francoise.praz@upmc.fr

Key Words: Hepatocellular carcinoma, microsatellite instability, cirrhosis, inflammation. distribution of risk factors for HCC is highly variable around the world. The HCC incidence is rising in Western countries, due to increasing $\mathrm{HCV}$ infection and non-alcoholic steatohepatitis (NASH) development (1). Several molecular classifications of HCC based on the comprehensive analysis of tumor genomes, epigenomes, and transcriptomes, have been established (2). These approaches led to identification of subgroups of tumors sharing recurrent alterations underlying the deregulation of cell cycle and signaling pathways (3), some of which being preferentially associated with a particular causative etiology (4). Several studies have investigated whether HCC might be associated with microsatellite instability (MSI), a well-known oncogenic pathway for other cancers such as colon and gastric cancers (Table I) (5-20). In these studies, the numbers of patients varied from eight to fifty-six $(19,20)$; the etiology of HCC, as well as the techniques used to screen MSI were highly variable, leading to conflicting results with the frequency of MSI ranging from $0-48 \%(7,14,17)$.

MSI tumors accumulate mutations due to a defect in mismatch repair (MMR), a DNA repair system dedicated to correcting the errors made by polymerases during replication. The MSI phenotype was originally described in hereditary nonpolyposis colorectal cancer, known as Lynch syndrome, in which MMR inactivation results from a monoallelic germline mutation of one of the MMR genes, most frequently MSH2 or MLH1, associated with the subsequent loss of the corresponding wild-type allele in the tumor $(21,22)$. Rare Lynch cases have recently been shown to result from germline EPCAM/TACSTD1 gene deletions leading to MSH2 promoter hypermethylation and transcription inhibition (23). Sporadic MSI colon tumors are twice as frequent as familial cases and generally occur as a consequence of abnormal hypermethylation of MLH1 promoter (24). Interestingly, MSI may be further due 
Table I. Previous studies on MSI in HCC.

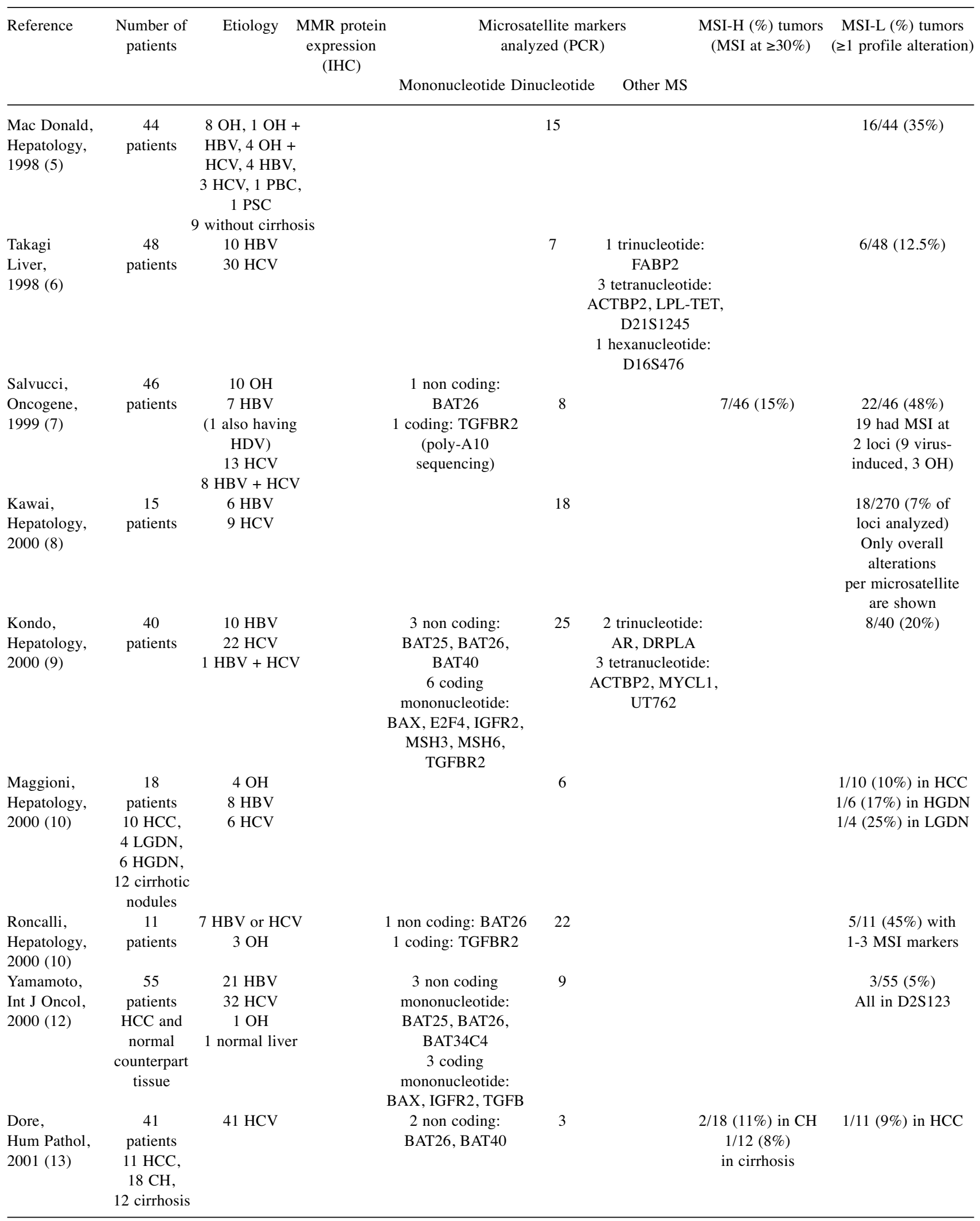


Table I. Continued

\begin{tabular}{|c|c|c|c|c|c|c|c|c|}
\hline \multirow[t]{2}{*}{ Reference } & \multirow[t]{2}{*}{$\begin{array}{l}\text { Number of } \\
\text { patients }\end{array}$} & \multirow[t]{2}{*}{ Etiology } & \multirow{2}{*}{$\begin{array}{l}\text { MMR protein } \\
\text { expression } \\
\text { (IHC) }\end{array}$} & \multicolumn{3}{|c|}{$\begin{array}{l}\text { Microsatellite markers } \\
\text { analyzed (PCR) }\end{array}$} & \multirow[t]{2}{*}{$\begin{array}{l}\text { MSI-H }(\%) \text { tumors } \\
\quad(\text { MSI at } \geq 30 \%)\end{array}$} & \multirow[t]{2}{*}{$\begin{array}{l}\text { MSI-L (\%) tumors } \\
\text { ( } \geq 1 \text { profile alteration) }\end{array}$} \\
\hline & & & & Mononucleotide & Dinucleotide & Other MS & & \\
\hline $\begin{array}{l}\text { Wang, } \\
\text { Int J Oncol, } \\
2001 \text { (14) }\end{array}$ & $\begin{array}{c}36 \\
\text { patients }\end{array}$ & $\begin{array}{c}3 \mathrm{HBV} \\
8 \mathrm{HCV} \\
3 \text { fibrolamellar }\end{array}$ & $\begin{array}{c}\text { MSH2, } \\
\text { MLH1: } \\
\text { all cases } \\
\text { positive for } \\
\text { both proteins }\end{array}$ & $\begin{array}{l}1 \text { non coding: } \\
\text { BAT26 }\end{array}$ & & & & $0 \%$ \\
\hline $\begin{array}{l}\text { Yang, } \\
\text { Int J Oncol, } \\
2001 \text { (15) }\end{array}$ & $\begin{array}{c}29 \\
\text { patients } \\
\text { HCC and } \\
\text { normal } \\
\text { counterpart } \\
\text { tissue }\end{array}$ & $29 \mathrm{HBV}$ & & & 5 & & $1 / 29(3 \%)$ & $4 / 29(13 \%)$ \\
\hline $\begin{array}{l}\text { Ho, } \\
\text { Hum Pathol, } \\
2003 \text { (16) }\end{array}$ & $\begin{array}{c}34 \\
\text { patients }\end{array}$ & $27 \mathrm{HBV}$ & & & 17 & $\begin{array}{l}1 \text { tetranu- } \\
\text { cleotide: } \\
\text { MYCL1 }\end{array}$ & $0 \%$ & $\begin{array}{c}1 / 34(3 \%) \text { at } \\
\text { only } 1 \mathrm{MS}\end{array}$ \\
\hline $\begin{array}{l}\text { Gross-Goupil, } \\
\text { Int J Cancer, } \\
2003 \text { (17) }\end{array}$ & $\begin{array}{c}18 \\
\text { patients } \\
39 \text { tumor } \\
\text { samples } \\
\text { (primary and } \\
\text { recurrences) }\end{array}$ & $\begin{array}{c}5 \mathrm{HBV} \\
8 \mathrm{HCV} \\
4 \mathrm{HBV} / \mathrm{HCV}\end{array}$ & & $\begin{array}{l}1 \text { non coding: } \\
\text { BAT } 26\end{array}$ & 18 & & $\begin{array}{c}2 / 18(11 \%) \\
\text { in primary } \\
0 \text { in recurrences }\end{array}$ & $\begin{array}{l}13 / 18(72 \%) \\
\text { in primary } \\
10 / 21(48 \%) \text { in } \\
\text { recurrences }\end{array}$ \\
\hline $\begin{array}{l}\text { Chiappini, } \\
\text { Carcinogenesis, } \\
2004 \text { (18) }\end{array}$ & $\begin{array}{c}37 \\
\text {, patients } \\
\text { HCC on } \\
\text { histologically } \\
\text { normal liver }\end{array}$ & $\begin{array}{c}\text { Low alcohol } \\
\text { consumption } \\
\text { no HBV } \\
\text { no HCV }\end{array}$ & $\begin{array}{c}\text { MSH2, } \\
\text { MLH1: } \\
\text { all cases } \\
\text { positive for } \\
\text { both proteins }\end{array}$ & $\begin{array}{l}3 \text { non coding: } \\
\text { BAT } 25, \\
\text { BAT26, } \\
\text { BAT40 }\end{array}$ & $\begin{array}{l}7 \text { (including } \\
\text { the } 3 \\
\text { "Bethesda" } \\
\text { dinucleotide } \\
\text { markers) }\end{array}$ & & $6 / 37(16 \%)$ & 10/37 (27\%) MSI-L \\
\hline $\begin{array}{l}\text { Zhang, } \\
\text { World J } \\
\text { Gastro, } \\
2005 \text { (19) }\end{array}$ & $\begin{array}{c}56 \\
\text { patients }\end{array}$ & $39 \mathrm{HBV}$ & & $\begin{array}{l}1 \text { non coding: } \\
\text { BAT26 }\end{array}$ & 54 & & $10 / 56(18 \%)$ & $8 / 56(14 \%)$ \\
\hline $\begin{array}{l}\text { Togni, } \\
\text { Hepatol Res, } \\
2009(20)\end{array}$ & $\begin{array}{c}8 \text { elderly } \\
\text { patients } \\
(\geq 60 \mathrm{y}) \\
\text { HCC on } \\
\text { normal liver }\end{array}$ & & $\begin{array}{l}\text { MSH2, MSH6, } \\
\text { MLH1, PMS2: } \\
\text { all cases } \\
\text { positive for } \\
\text { all } 4 \text { proteins }\end{array}$ & $\begin{array}{c}5 \text { non coding: } \\
\text { BAT25, } \\
\text { BAT26, } \\
\text { NR21, } \\
\text { NR24, NR27 }\end{array}$ & & & $0 \%$ & $0 \%$ \\
\hline
\end{tabular}

$\mathrm{CH}$, Chronic hepatitis; HGDN, high-grade dysplastic nodule; LGDN, low-grade dysplastic nodule; PBC, primary biliary cirrhosis; PSC, primary sclerosing cholangitis.

to other molecular alterations arising in various pathological situations, notably when mutations occur at very high frequencies, outweighing the MMR capabilities. For example, MSI lymphomas have been reported in immunodeficient patients, due to HIV infection or to iatrogenic immunosuppressive treatment for transplantation (25). Low levels of MSI may also be favored by chronic inflammation or oxidative stress $(26,27)$, as reported in pancreatitis $(28)$ and ulcerative colitis, a chronic disease characterized by free radical stress and colon cancer proneness (29). Interestingly, microRNAs-155 (30) and -21 (31), two major miRNAs in hepatocellular oncogenesis that are also overexpressed in inflammatory bowel diseases (32), down-regulate the expression of MMR core proteins, MSH2 and MLH1 $(33,34)$. Lastly, MMR protein expression defects and MSI have been reported in the inflammation-associated malignant transformation of endometriosis (35). Altogether, these observations indicate that some cases of HCC, especially those associated with a high degree of inflammation, might display some degree of MSI.

Microsatellites are simple sequence repeats of one to six nucleotides, which are particularly prone to insertion or deletion (indel) mutations during replication. In absence of a functional MMR system, indel mutations are left unrepaired and appear as novel alleles with altered lengths. 
Table II. Clinicopathological characteristics of patients with HCC in relation with surgical management.

\begin{tabular}{|c|c|c|c|}
\hline & $\begin{array}{l}\text { Patients undergoing } \\
\text { tumor resection } \\
(\mathrm{n}=88)\end{array}$ & $\begin{array}{l}\text { Patients undergoing } \\
\text { transplantation } \\
(\mathrm{n}=34)\end{array}$ & $p$-Value \\
\hline Median age, years [range] & $60.7[17.8-83.2]$ & $56.8[41.6-68.0]$ & 0.042 \\
\hline \multicolumn{4}{|l|}{ Gender, $\mathrm{n}(\%)$} \\
\hline Male & $70(79.5)$ & $24(70.6)$ & 0.34 \\
\hline Female & $18(20.5)$ & $10(29.4)$ & \\
\hline Liver disease etiology, $\mathrm{n}$ & & & 0.21 \\
\hline Chronic alcohol abuse only & 9 & 3 & \\
\hline HBV & 20 & 5 & \\
\hline $\mathrm{HCV}$ & 27 & 17 & \\
\hline NASH & 19 & 4 & \\
\hline Others $^{\mathrm{a}}$ & 5 & 4 & \\
\hline Unknown (normal liver) & 8 & 1 & \\
\hline Preoperative treatment, $\mathrm{n}(\%)$ & $26(29.5)$ & $20(58.8)$ & 0.0037 \\
\hline Resection before LT & - & $5(14.7)$ & \\
\hline Radiofrequency & 0 & $5(14.7)$ & \\
\hline Chemoembolization & $15(17.0)$ & $12(35.3)$ & \\
\hline Other neoadjuvant therapy ${ }^{b}$ & $5(5.7)$ & 0 & \\
\hline \multicolumn{4}{|l|}{ Pathological characteristics } \\
\hline Cirrhosis, n/N (\%) & $51 / 88(58.0)$ & $34 / 34(100)$ & $<0.0001$ \\
\hline Tumor size, median [range] (mm) & $50[10-230]$ & $25.5[5-60]$ & $<0.0001$ \\
\hline Single HCC, n/N (\%) & $67 / 88(76.1)$ & $16 / 29(57.2)$ & $\mathbf{0 . 0 3 7}$ \\
\hline \multicolumn{4}{|l|}{ Differentiation grade, $\mathrm{n} / \mathrm{N}(\%)$} \\
\hline Well & $23 / 86(26.8)$ & $12 / 33(36.4)$ & \\
\hline Moderate & $45 / 86(52.3)$ & $19 / 33(57.6)$ & 0.13 \\
\hline Poor & $18 / 86(20.9)$ & $2 / 33(6.0)$ & \\
\hline
\end{tabular}

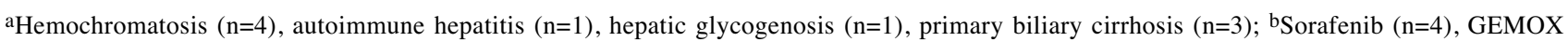
$(\mathrm{n}=1)$. HBV, hepatitis B virus; HCC, hepatocellular carcinoma; HCV, hepatitis C virus; LT, liver transplantation; NASH, nonalcoholic steatohepatitis; PVE, portal vein embolization. The age and tumor size of patients who underwent tumor resection were compared to those receiving a liver transplant using the unpaired $t$-test with Welch's correction. Tumor etiologies and differentiation grades were compared using the Chi-square test. All other clinicopathological characteristics were compared using two-sided Fisher's exact test. $p$-Values below 0.05 considered as statistically significant are shown in bold.

Such novel alleles are classically looked for using various PCR techniques designed to detect MSI tumors. In 1997, an international consensus meeting recommended a panel of five markers, two mononucleotide and three dinucleotide repeat markers, to analyze MSI in colorectal tumors (36). Using this so-called "Bethesda panel", tumors were diagnosed as MSI-High (MSI-H) when displaying instability at two ore more of these markers (36). Later, a pentaplex PCR system comprising five mononucleotide repeats, and allowing $100 \%$ sensitivity and specificity with no need to match corresponding normal DNA, became the gold standard in MSI colorectal cancer screening $(37,38)$. Analysis of MMR protein expression by immunohistochemistry (IHC) is also very popular, with MSH2 and MLH1 being performed in routine while MSH6 and PMS2 are analyzed in rare studies. In HCC, MSI has been investigated by $\operatorname{IHC}(14,18,20)$, and by PCR using highly variable sets of microsatellite loci $(5,6,9-11,13-20,39)$ (Table I).
The aim of this study was to assess the MSI prevalence in a large series of HCC including various etiologies, representative of the Western HCC population, using the highly sensitive gold-standard mononucleotide pentaplex PCR method, together with 13 polymorphic dinucleotide markers.

\section{Materials and Methods}

Patients and tumor samples. The study population consisted of 122 patients with histologically-proven HCC who underwent surgery at the Saint-Antoine Hospital, Paris. Each patient provided informed consent for research, and the study has been conducted in accordance with the French laws and regulations. Among them, 88 $(72.1 \%)$ underwent liver tumor resection and 34 (27.9\%) received liver transplantation. There was no significant difference in the underlying liver disease spectrum between the two groups of patients, which was related to chronic alcohol abuse only in 12 patients $(9.8 \%)$, HCV infection in 44 patients $(36 \%)$, HBV infection in 25 patients (20.5\%), and NASH in 23 patients (18.9\%). 
The diagnosis of cirrhosis based on histology was positive for $84 / 121(69 \%)$ patients. The surrounding liver showed no sign of fibrosis at the initial pathological examination in 17 patients undergoing tumor resection $(19.3 \%)$. The tumor size was the largest diameter measured by imaging. The major clinical and pathological characteristics of patients are summarized in Table II. Tumor samples obtained from resected or explanted livers with HCC were retrieved from the HUEP tumor biobank (Pathology department, Saint-Antoine hospital, Hôpitaux Universitaires Est Parisien, AP-HP).

DNA extraction and microsatellite instability analysis. DNA was extracted using the Nucleospin Tissue DNA isolation kit (Macherey Nagel) for the frozen samples ( $n=88)$, and the Express extract DNA extraction kit (Kappa Biosystems) for the paraffin-embedded samples $(n=34)$, according to the manufacturers instructions. MSI analysis was carried out using 5 quasi-monomorphic mononucleotide repeats markers (BAT25, BAT26, NR21, NR22, NR24) co-amplified in a single pentaplex PCR reaction (40), and 13 highly polymorphic dinucleotide repeat markers (2p16: D2S123; 5q14: D5S107; 8p22: D8S1731, D8S261; 11q13: D11S937, D11S911; 17p12: D17S1791; 17q11: D17S1824, D17S1873; 18p11: D18S53, D18S1114, D18S1132; 18q21: D18S1127). For dinucleotide repeats, the number of markers that could be coamplified varied from 2 to 5, depending on the amplification efficacy of each primer set and whether DNA was extracted from frozen or paraffin-embedded samples. Primer sequences, chromosome location and amplicon size of the mononucleotide and dinucleotide repeats analyzed are available upon request; forward primers were 5'-end-labeled with a fluorescent dye (FAM, HEX or Dragon Fly Orange, Eurogentec). Amplification of DNA extracted from frozen tumors, was performed using Taq DNA Polymerase (Qiagen), starting with an initial 3 min denaturation step at $95^{\circ} \mathrm{C}$, followed by 35 cycles at $95^{\circ} \mathrm{C}$ for $30 \mathrm{sec}, 60^{\circ} \mathrm{C}$ for $30 \mathrm{sec}$ and $72^{\circ} \mathrm{C}$ for $30 \mathrm{sec}$, with a final extension at $72^{\circ} \mathrm{C}$ for $1 \mathrm{~min}$. DNA extracted from paraffin-embedded tumors were amplified using the KAPA2G Robust HotStart ReadyMix because it is efficient on crude DNA preparations possibly containing enzyme inhibitors, such as those obtained from paraffin-embedded samples (KAPA BIOSYSTEMS); the PCR conditions were the same except that the duration of each step was $15 \mathrm{sec}$. Adequate dilutions of the PCR products were run on an ABI PRISM ${ }^{\circledR} 3100$ Genetic Analyzer (Applied Biosystems) using Performance Optimized Polymer-7 (Applied Biosystems) and HD400 ROX Size Standard (Applied Biosystems); allelic sizes were defined using the GeneMapper Software (Applied Biosystems).

Statistical analyses. The age and tumor size of patients who underwent tumor resection were compared to those receiving a liver transplant using the unpaired $t$-test with Welch's correction. The tumor etiologies and differentiation grades were compared using the Chi-square test. All other clinicopathological characteristics were compared using the two-sided Fisher's exact test. The numbers of alleles displaying altered profiles in tumors were compared using the unpaired $t$-test with Welch's correction. The relationship between the level of MSI and the etiology or the differentiation grade was evaluated using the Kruskal-Wallis test. The impact of cirrhosis on the level of MSI was analyzed by a one-sided MannWhitney test. A two-sided Mann-Whitney test was used to evaluate the impact of tumor size or number on the level of MSI. $p$-Values below 0.05 were considered statistically significant.

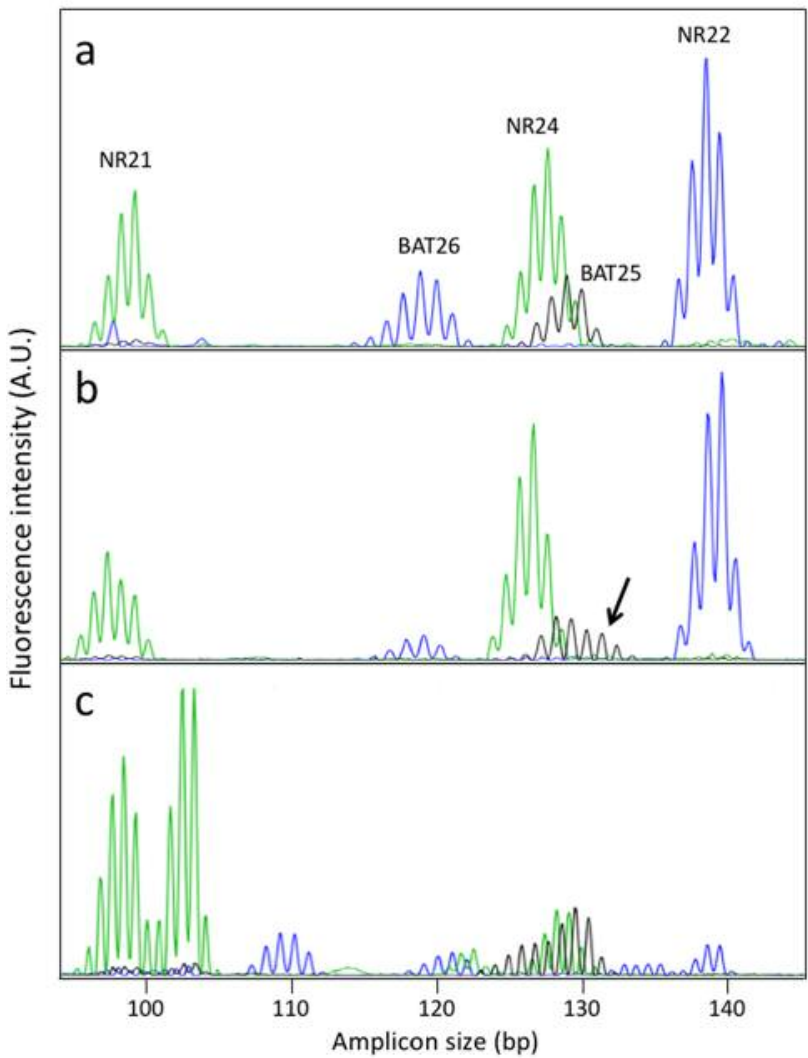

Figure 1. Examples of pentaplex PCR of mononucleotide repeats. (1a) Typical profile of a tumor devoid of microsatellite instability; (1b) HCC case displaying an atypical profile at the BAT25 marker, (1c) typical profile of an MSI colorectal tumor.

\section{Results}

Abnormal profiles consisting in the insertion or deletion of few nucleotides have been observed in 8 tumors ( 1 at NR21, 1 at BAT26, and 6 at BAT25) (Table III). Figure 1 shows an example of the profiles of the mononucleotide repeats pentaplex PCR performed on tumors showing either a normal profile at all 5 markers (Figure 1a) or displaying an abnormal BAT25 profile (Figure 1b). The shifts occurring in BAT25 are less marked than in a typical MSI colorectal cancer that displays extensive instability, used as a positive control (Figure 1c). The possibility that atypical MS profiles were due to PCR artifacts arising early during the PCR was systematically ruled out by repeating the amplification reactions. The results obtained for tumors retrieved from patients who underwent tumor resection or liver transplantation are shown in Table III. The frequencies of abnormal profiles were comparable in frozen and paraffinembedded samples (4/439 vs. 4/162, $p=0.22$; data can be 
Table III. MS profiles in tumor samples of patients with hepatocellular carcinoma. Normal profiles are shown in grey, abnormal profiles are shown in black, rectangles with a cross indicate that DNA could not be amplified, open rectangles indicate samples that have not been investigated. For each tumor sample, the number of markers analyzed, the number of abnormal profiles and the percentage of abnormal profiles are indicated in the last three columns. Tumor identifiers in the left column start with an $R$ or a $T$ to indicate whether patient underwent tumor resection $(R)$ or transplantation (T); a $P$ at the end indicates paraffin-embedded samples. Abbreviation: MS, microsatellite.

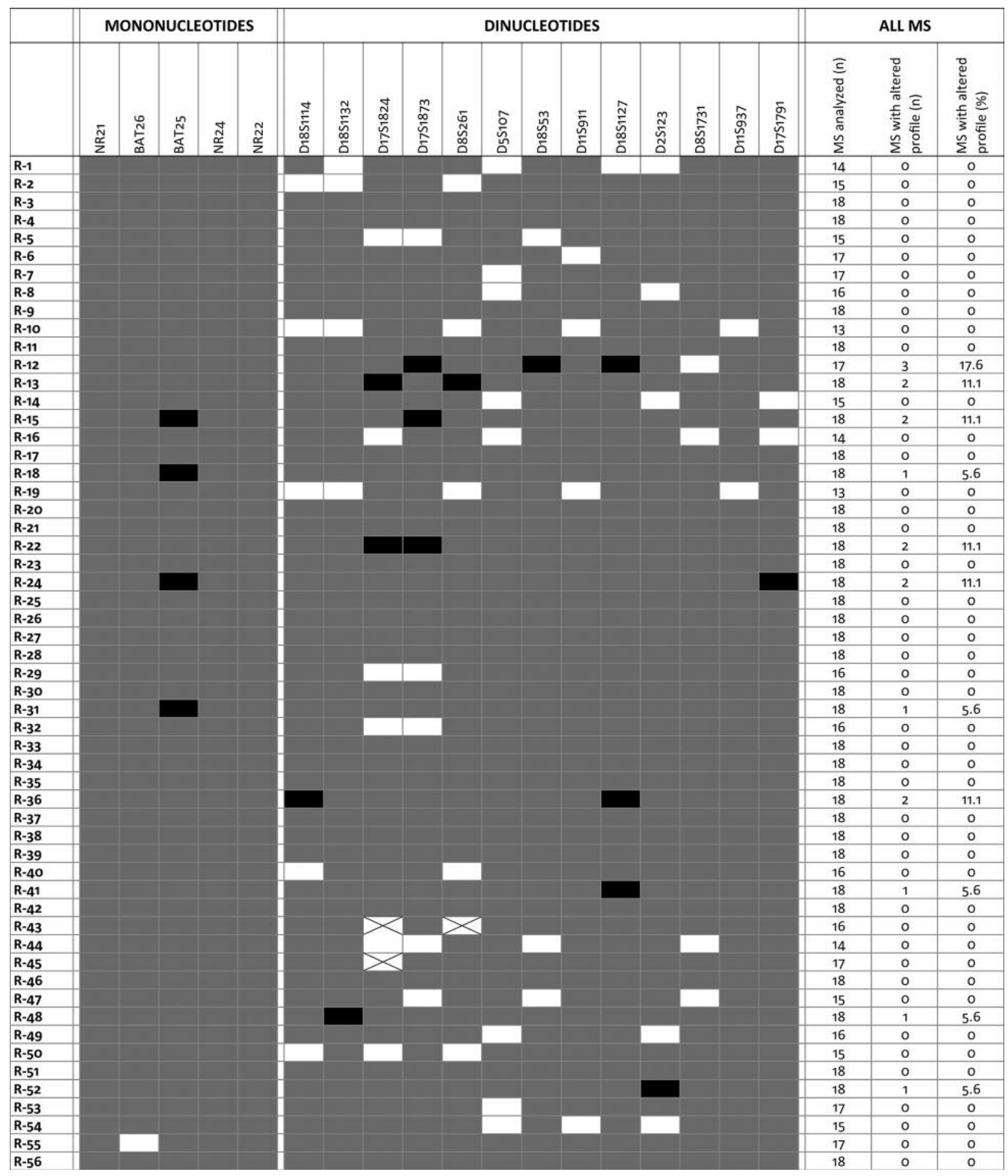

Table III. Continued 
Table III. Continued

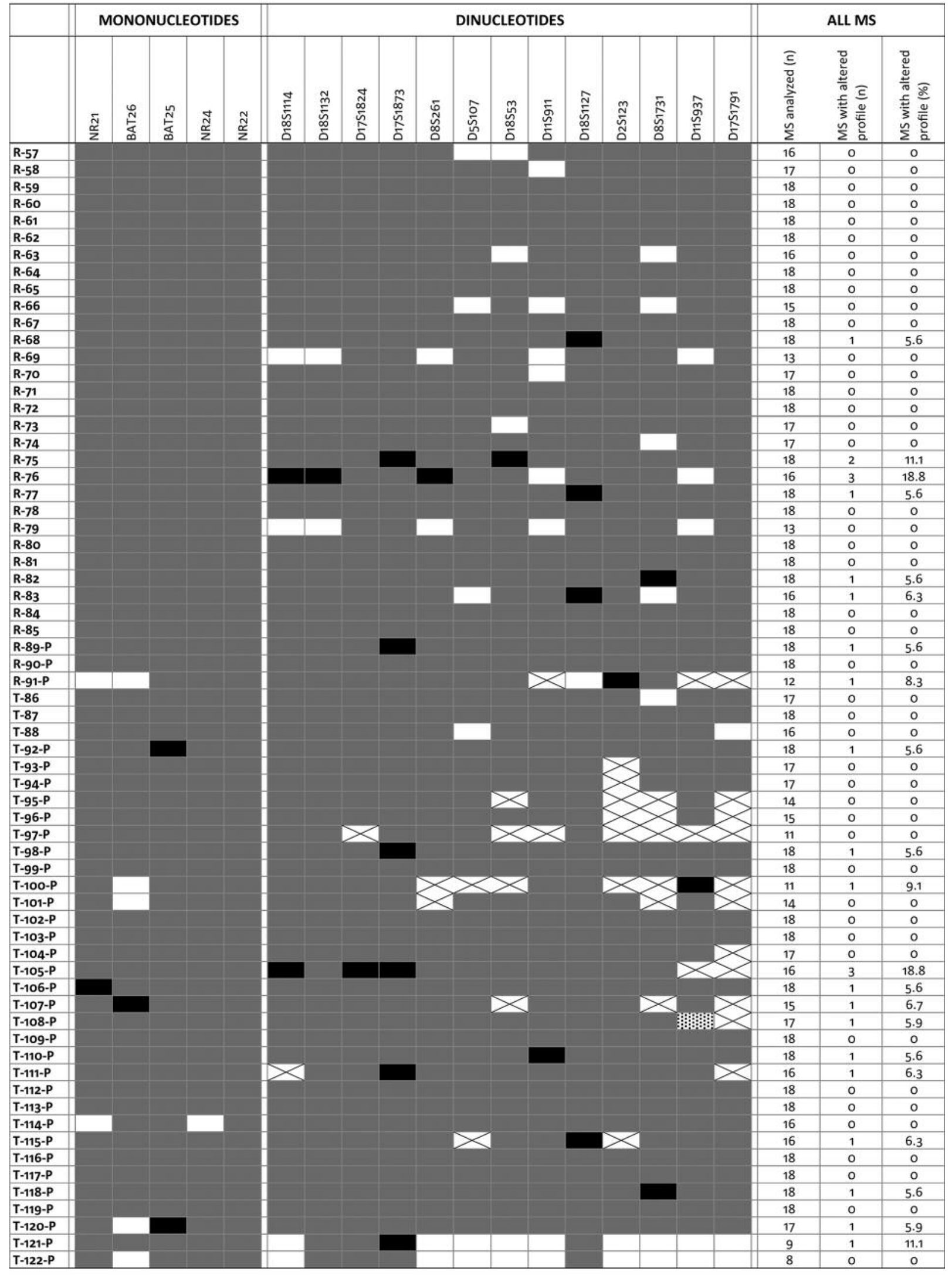


Table IV. Relationship between MSI levels and clinicopathological characteristics

\begin{tabular}{|c|c|c|c|c|c|}
\hline & \multirow[t]{2}{*}{ Number of tumors } & \multicolumn{3}{|c|}{ MSI (\%) } & \multirow[t]{2}{*}{$p$-Value } \\
\hline & & Mean & $95 \%$ CI of mean & [Range] & \\
\hline \multicolumn{6}{|l|}{ Liver disease etiology } \\
\hline Alcohol & 12 & 2.08 & {$[0.0-4.591]$} & {$[0.0-11.1]$} & 0.7855 \\
\hline $\mathrm{HBV}$ & 25 & 2.62 & {$[0.309-4.931]$} & {$[0.0-18.8]$} & \\
\hline $\mathrm{HCV}$ & 44 & 2.41 & {$[1.247-3.571]$} & {$[0.0-11.1]$} & \\
\hline NASH & 23 & 1.75 & {$[0.0-3.521]$} & {$[0.0-17.6]$} & \\
\hline Unknown (normal liver) & 8 & 0.79 & {$[0.0-2.650]$} & {$[0.0-6.3]$} & \\
\hline \multicolumn{6}{|l|}{ Pathological characteristics } \\
\hline No cirrhosis & 37 & 1.43 & {$[1.578-3.436]$} & {$[0.0-18.8]$} & 0.0512 \\
\hline Cirrhosis & 85 & 2.51 & {$[0.148-2.717]$} & {$[0.0-18.8]$} & \\
\hline Tumor size $\leq 5 \mathrm{~cm}$ & 75 & 1.887 & {$[0.950-2.783]$} & {$[0.0-18.8]$} & 0.2612 \\
\hline Tumor size $>5 \mathrm{~cm}$ & 47 & 2.683 & {$[1.263-4.003]$} & {$[0.0-18.8]$} & \\
\hline Single HCC & 78 & 1.936 & {$[1.081-2.791]$} & {$[0.0-17.6]$} & 0.5277 \\
\hline Multiple HCC & 44 & 2.616 & {$[1.148-4.084]$} & {$[0.0-18.8]$} & \\
\hline \multicolumn{6}{|l|}{ Differentiation } \\
\hline Well & 36 & 1.933 & {$[0.590-3.276]$} & {$[0.0-18.8]$} & 0.8544 \\
\hline Moderate & 64 & 2.289 & {$[1.218-3.360]$} & {$[0.0-18.8]$} & \\
\hline Poor & 20 & 1.945 & {$[0.008-3.882]$} & [0.0-11.1] & \\
\hline
\end{tabular}

The relationship between the level of MSI and the etiology or the diffentiation grade was evaluated using the Kruskal-Wallis test. The impact of cirrhosis was analyzed using a one-sided Mann-Whitney test. A two-sided Mann-Whitney test was used to evaluate the impact of tumor size or number.

retrieved from Table III). Among the 122 HCC tumors analyzed, none could be considered as displaying a typical MSI-H phenotype as defined by instability in at least 3 of the 5 mononucleotide repeats analyzed. Yet, 8 tumors displayed instability at 1 mononucleotide repeat.

We further screened for instability at 13 dinucleotide repeated loci located on 8 different regions of the genome, with the size of the amplicons varying from 78 to $290 \mathrm{bp}$. The rates of abnormal profiles in dinucleotide repeats did not differ significantly when comparing frozen and paraffinembedded tumors ( $p=0.19$, data not shown). The majority of samples (90/122) displayed no detectable instability at any of the 13 dinucleotide repeat loci analyzed. At maximum, 3 abnormal profiles could be detected in 3 tumors (Table III), which is not enough to classify these tumors as MSI-H. According to the recommendations established for colorectal cancers, a tumor should display instability at $\geq 30-40 \%$ of dinucleotide repeats to be considered as MSI-H, meaning 4 out of the 13 markers analyzed in our conditions. Interestingly, low levels of MSI were observed in one-fourth of the tumors (38/122). Moreover, the level of MSI was not related to the etiology of the underlying liver disease, the differentiation grade, the size or number of liver tumors, but tended to be higher in patients with cirrhosis $(p=0.051)$ (Table IV).

\section{Discussion}

The aim of our study was to appraise whether MSI could contribute to HCC oncogenesis, and if instability might be preferentially associated with a specific etiology and/or treatment. Previously published studies that addressed this question varied tremendously in terms of HCC etiology, a characteristic that depends largely on the geographical origin of the patients, and in the number of tumors analyzed that was between 8 and $56(5,6,9-20,39)$. Furthermore, the type and number of markers also varied considerably from a single mononucleotide repeat marker (14) to 55 microsatellite markers, mostly dinucleotide repeated sequences (19); few studies also included trinucleotide, tetranucleotide and hexanucleotide repeats whose genetic stability may involve DNA repair pathways other than $\operatorname{MMR}(6,9,16)$. Most studies screened MSI using PCR technique, but the definition of MSI was not always clearly specified, which makes the comparisons between the published data even more hazardous. Reported MSI frequency in HCC varied between 0-48\%, with a frequency of MSI-H tumors varying from $0-18 \%$ when taking into account the consensus definition for MSI-H tumors. Several reasons may contribute to the variability observed in the data published: (i) analyses of MSI profiles using highly polymorphic markers other than mononucleotide 
repeats are somehow tricky to interpret outside of well-trained laboratories and may lead to misinterpretation, (ii) the number of samples analyzed was often too limited to definitely establish the percentage of MSI, (iii) underlying etiology differed widely among studies. Lastly, the only study performed using the recently developed highly efficient mononucleotide pentaplex PCR system investigated no more than eight cases of HCC; besides these tumors all occurred in elderly patients with no chronic liver disease (20). Based on our expertise in analyzing microsatellite profiles (41-47), we investigated MSI in a large collection of HCC of various etiologies using robust and accurate PCR-based MSI testing techniques, both at mononucleotide repeats, using the goldstandard pentaplex PCR based on five nearly monomorphic mononucleotide markers, and at 13 dinucleotide repeats located on 8 different chromosomes.

MSH2/MSH6 complexes, known as MutS $\alpha$, are able to efficiently bind to most base-base mismatches (with the exception of CC mismatches), and to loops of one or two nucleotides, whereas MutS $\beta$, consisting of MSH2 and MSH3, preferentially repairs larger heteroduplexes loops, such as those resulting from indel of dinucleotide repeats. Excision of the newly replicated DNA fragment containing a mismatch involves MLH1/PMS2 complex, referred as MutL $\alpha$, that acts upon binding of either MutS $\alpha$ or MutS $\beta$. Thus, analyzing instability at both mononucleotide and dinucleotide repeated sequences is needed to investigate these partially redundant DNA repair systems. The goldstandard screening method for MSI in colorectal cancers is now based solely on the analysis of mononucleotide repeats, which are particularly prone to slippage during replication as they harbour high number of repeated motifs. Yet, this method is adequate in the case of colorectal cancers, as we know that MSI results from a defect in one of the component of MutS $\alpha$ or MutL $\alpha$ (MSH2, MSH6, MLH1, PMS2). However, in the case of $\mathrm{HCC}$, we considered the possibility that MSI might arise through other mechanisms. Consequently, we included dinucleotide repeats in our panel to investigate the possibility of a defect in MutS $\beta$.

Though none of the HCC analyzed could be classified as MSI-H, microsatellite instability arose at one locus or more in one-fourth of the HCC analyzed, without being associated with a particular underlying liver disease etiology. Mononucleotide and dinucleotide repeats were equally frequently altered when taking into consideration the number of markers of each type analyzed. Interestingly, the level of MSI tended to be higher in patients with cirrhosis, a difference that failed to reach statistical significance ( $p=0.051)$, but corroborates the existence of a link between inflammation and genetic instability (48).

Interestingly, a recent study showed that cells lacking the H3K36 trimethyltransferase SETD2 display MSI and an elevated spontaneous mutation frequency, characteristic of
MMR deficient cells (49). Thus, it is tempting to propose that deleterious mutations of SETD2 such as those recently reported in a subset of HCC (2) may be responsible, at least in part, in microsatellite alterations arising in these tumors. Whether other mechanisms known to disturb the histone $\mathrm{H} 3$ methylation status, such as the HCV nonstructural protein $5 \mathrm{~A}$ that has been shown to interact with the lysine methyltransferase SET and MYND domain-containing 3 (SMYD3) (50), may also induce MSI remains to be investigated on large series of HCV-related HCC.

In conclusion, our observations made with highly sensitive and specific panel markers on a large series of HCC indicate that low levels of genetic instability in both mononucleotide and dinucleotide repeated sequences occur quite commonly in HCC, independently of the etiology of the underlying liver disease. The molecular mechanisms inducing low MSI in HCC remain to be identified. They may differ among tumours, possibly involving chronic oxidative stress and inflammation that are hallmarks of liver cancers, or deleterious mutations in SETD2, as recently described in a minority of cases of HCC (2). Whether low MSI levels have an impact on the prognosis of $\mathrm{HCC}$, as in the case of colorectal cancer, remains to be investigated.

\section{Conflicts of Interest}

The Authors have no other relevant affiliations or financial involvement with any organization or entity with a financial interest in or financial conflict with the subject matter or materials discussed in the manuscript.

\section{Acknowledgements}

Claire GOUMARD was a recipient of a grant from the Institut National du Cancer (French National Cancer Institute). The funding source had no role in study design, data collection, data analysis, data interpretation or the writing of the report. The authors thank Pr Olivier ROSMORDUC and Dr Laëtitia FARTOUX for their contribution to the care of patients with HCC. They further thank the HUEP tumor biobank (Pathology Department, Saint-Antoine Hospital, Hôpitaux Universitaires Est Parisien, AP-HP) for providing good quality tumor samples, as well Sylvie DUMONT for her expert technical help in managing them (LUMIC histomorphology technological platform, UMS30, UPMC, Paris).

\section{References}

1 El-Serag HB: Hepatocellular carcinoma. N Engl J Med 365: 1118-1127, 2011.

2 Schulze K, Imbeaud S, Letouze E, Alexandrov LB, Calderaro J, Rebouissou S, Couchy G, Meiller C, Shinde J, Soysouvanh F, Calatayud AL, Pinyol R, Pelletier L, Balabaud C, Laurent A, Blanc JF, Mazzaferro V, Calvo F, Villanueva A, Nault JC, Bioulac-Sage P, Stratton MR, Llovet JM and Zucman-Rossi J: Exome sequencing of hepatocellular carcinomas identifies new mutational signatures and potential therapeutic targets. Nat Genet 47: 505-511, 2015. 
3 Hass HG, Vogel U, Scheurlen M and Jobst J: Gene-expression analysis identifies specific patterns of dysregulated molecular pathways and genetic subgroups of human hepatocellular carcinoma. Anticancer Res 36: 5087-5095, 2016.

4 Shibata $\mathrm{T}$ and Aburatani $\mathrm{H}$ : Exploration of liver cancer genomes. Nat Rev Gastroenterol Hepatol 11: 340-349, 2014.

5 Macdonald GA, Greenson JK, Saito K, Cherian SP, Appelman HD and Boland CR: Microsatellite instability and loss of heterozygosity at DNA mismatch repair gene loci occurs during hepatic carcinogenesis. Hepatology 28: 90-97, 1998.

6 Takagi K, Esumi M, Takano S and Iwai S: Replication error frequencies in primary hepatocellular carcinoma: A comparison of solitary primary versus multiple primary cancers. Liver 18 : 272-276, 1998.

7 Salvucci M, Lemoine A, Saffroy R, Azoulay D, Lepere B, Gaillard S, Bismuth H, Reynes M and Debuire B: Microsatellite instability in european hepatocellular carcinoma. Oncogene 18 : 181-187, 1999.

8 Kawai H, Suda T, Aoyagi Y, Isokawa O, Mita Y, Waguri N, Kuroiwa T, Igarashi M, Tsukada K, Mori S, Shimizu T, Suzuki Y, Abe Y, Takahashi T, Nomoto M and Asakura H: Quantitative evaluation of genomic instability as a possible predictor for development of hepatocellular carcinoma: Comparison of loss of heterozygosity and replication error. Hepatology 31: 1246$1250,2000$.

9 Kondo Y, Kanai Y, Sakamoto M, Mizokami M, Ueda R and Hirohashi S: Genetic instability and aberrant DNA methylation in chronic hepatitis and cirrhosis - a comprehensive study of loss of heterozygosity and microsatellite instability at 39 loci and DNA hypermethylation on $8 \mathrm{CpG}$ islands in microdissected specimens from patients with hepatocellular carcinoma. Hepatology 32: 970-979, 2000.

10 Maggioni M, Coggi G, Cassani B, Bianchi P, Romagnoli S, Mandelli A, Borzio M, Colombo P and Roncalli M: Molecular changes in hepatocellular dysplastic nodules on microdissected liver biopsies. Hepatology 32: 942-946, 2000.

11 Roncalli M, Bianchi P, Grimaldi GC, Ricci D, Laghi L, Maggioni M, Opocher E, Borzio M and Coggi G: Fractional allelic loss in non-end-stage cirrhosis: Correlations with hepatocellular carcinoma development during follow-up. Hepatology 31: 846-850, 2000.

12 Yamamoto H, Itoh F, Fukushima H, Kaneto H, Sasaki S, Ohmura T, Satoh T, Karino Y, Endo T, Toyota J and Imai K: Infrequent widespread microsatellite instability in hepatocellular carcinomas. Int J Oncol 16: 543-547, 2000.

13 Dore MP, Realdi G, Mura D, Onida A, Massarelli G, Dettori G, Graham DY and Sepulveda AR: Genomic instability in chronic viral hepatitis and hepatocellular carcinoma. Hum Pathol 32: 698-703, 2001.

14 Wang L, Bani-Hani A, Montoya DP, Roche PC, Thibodeau SN, Burgart LJ and Roberts LR: hMLH1 and hMSH2 expression in human hepatocellular carcinoma. Int J Oncol 19: 567-570, 2001.

15 Yang EB, Zhao YN, Zhang K and Mack P: Microsatellite alterations in human hepatocellular carcinoma infected with hepatitis B virus: Associated with the elevation of serum alphafetoprotein. Int J Oncol 19: 513-518, 2001.

16 Ho MK, Lee JM, Chan CK and Ng IO: Allelic alterations in nontumorous liver tissues and corresponding hepatocellular carcinomas from chinese patients. Hum Pathol 34: 699-705, 2003.
17 Gross-Goupil M, Riou P, Emile JF, Saffroy R, Azoulay D, Lacherade I, Receveur A, Piatier-Tonneau D, Castaing D, Debuire B and Lemoine A: Analysis of chromosomal instability in pulmonary or liver metastases and matched primary hepatocellular carcinoma after orthotopic liver transplantation. Int J Cancer 104: 745-751, 2003.

18 Chiappini F, Gross-Goupil M, Saffroy R, Azoulay D, Emile JF, Veillhan LA, Delvart V, Chevalier S, Bismuth H, Debuire B and Lemoine A: Microsatellite instability mutator phenotype in hepatocellular carcinoma in non-alcoholic and non-virally infected normal livers. Carcinogenesis 25: 541-547, 2004.

19 Zhang SH, Cong WM, Xian $\mathrm{ZH}$ and $\mathrm{Wu} \mathrm{MC}$ : Clinicopathological significance of loss of heterozygosity and microsatellite instability in hepatocellular carcinoma in China. World J Gastroenterol 11: 3034-3039, 2005.

20 Togni R, Bagla N, Muiesan P, Miquel R, O’Grady J, Heaton N, Knisely AS, Portmann B and Quaglia A: Microsatellite instability in hepatocellular carcinoma in non-cirrhotic liver in patients older than 60 years. Hepatol Res 39: 266-273, 2009.

21 Jacob S and Praz F: DNA mismatch repair defects: Role in colorectal carcinogenesis. Biochimie 84: 27-47, 2002.

22 Sijmons RH and Hofstra RM: Review: Clinical aspects of hereditary DNA mismatch repair gene mutations. DNA Repair (Amst) 38: 155-162, 2016.

23 Rumilla K, Schowalter KV, Lindor NM, Thomas BC, Mensink KA, Gallinger S, Holter S, Newcomb PA, Potter JD, Jenkins MA, Hopper JL, Long TI, Weisenberger DJ, Haile RW, Casey G, Laird PW, Le Marchand L and Thibodeau SN: Frequency of deletions of EPCAM (TACSTD1) in MSH2-associated lynch syndrome cases. J Mol Diagn 13: 93-99, 2011.

24 Kane MF, Loda M, Gaida GM, Lipman J, Mishra R, Goldman H, Jessup JM and Kolodner R: Methylation of the hMLH1 promoter correlates with lack of expression of hMLH1 in sporadic colon tumors and mismatch repair-defective human tumor cell lines. Cancer Res 57: 808-811, 1997.

25 Duval A, Raphael M, Brennetot C, Poirel H, Buhard O, Aubry A, Martin A, Krimi A, Leblond V, Gabarre J, Davi F, Charlotte F, Berger F, Gaidano G, Capello D, Canioni D, Bordessoule D, Feuillard J, Gaulard P, Delfau MH, Ferlicot S, Eclache V, Prevot S, Guettier C, Lefevre PC, Adotti F and Hamelin R: The mutator pathway is a feature of immunodeficiency-related lymphomas. Proc Natl Acad Sci USA 101: 5002-5007, 2004.

26 Gasche C, Chang CL, Rhees J, Goel A and Boland CR: Oxidative stress increases frameshift mutations in human colorectal cancer cells. Cancer Res 61: 7444-7448, 2001.

27 Chang CL, Marra G, Chauhan DP, Ha HT, Chang DK, Ricciardiello L, Randolph A, Carethers JM and Boland CR: Oxidative stress inactivates the human DNA mismatch repair system. Am J Physiol Cell Physiol 283: C148-154, 2002.

28 Brentnall TA, Chen R, Lee JG, Kimmey MB, Bronner MP, Haggitt RC, Kowdley KV, Hecker LM and Byrd DR: Microsatellite instability and K-ras mutations associated with pancreatic adenocarcinoma and pancreatitis. Cancer Res 55: 4264-4267, 1995.

29 Brentnall TA, Crispin DA, Bronner MP, Cherian SP, Hueffed M, Rabinovitch PS, Rubin CE, Haggitt RC and Boland CR: Microsatellite instability in nonneoplastic mucosa from patients with chronic ulcerative colitis. Cancer Res 56: 1237-1240, 1996.

30 Han ZB, Chen HY, Fan JW, Wu JY, Tang HM and Peng ZH: Upregulation of microRNA-155 promotes cancer cell invasion and 
predicts poor survival of hepatocellular carcinoma following liver transplantation. J Cancer Res Clin Oncol 138: 153-161, 2012.

31 Zhu Q, Wang Z, Hu Y, Li J, Li X, Zhou L and Huang Y: miR21 promotes migration and invasion by the miR-21-PDCD4-AP1 feedback loop in human hepatocellular carcinoma. Oncol Rep 27: 1660-1668, 2012

32 Svrcek M, El-Murr N, Wanherdrick K, Dumont S, Beaugerie L, Cosnes J, Colombel JF, Tiret E, Flejou JF, Lesuffleur T and Duval A: Overexpression of micrornas-155 and 21 targeting mismatch repair proteins in inflammatory bowel diseases. Carcinogenesis 34: 828-834, 2013.

33 Valeri N, Gasparini P, Fabbri M, Braconi C, Veronese A, Lovat F, Adair B, Vannini I, Fanini F, Bottoni A, Costinean S, Sandhu SK, Nuovo GJ, Alder H, Gafa R, Calore F, Ferracin M, Lanza G, Volinia S, Negrini M, McIlhatton MA, Amadori D, Fishel R and Croce CM: Modulation of mismatch repair and genomic stability by miR-155. Proc Natl Acad Sci USA 107: 6982-6987, 2010.

34 Valeri N, Gasparini P, Braconi C, Paone A, Lovat F, Fabbri M, Sumani KM, Alder H, Amadori D, Patel T, Nuovo GJ, Fishel R and Croce CM: MicroRNA-21 induces resistance to 5fluorouracil by down-regulating human DNA MutS homolog 2 (hMSH2). Proc Natl Acad Sci USA 107: 21098-21103, 2010.

35 Fuseya C, Horiuchi A, Hayashi A, Suzuki A, Miyamoto T, Hayashi T and Shiozawa T: Involvement of pelvic inflammationrelated mismatch repair abnormalities and microsatellite instability in the malignant transformation of ovarian endometriosis. Hum Pathol 43: 1964-1972, 2012.

36 Boland CR, Thibodeau SN, Hamilton SR, Sidransky D, Eshleman JR, Burt RW, Meltzer SJ, Rodriguez-Bigas MA, Fodde R, Ranzani GN and Srivastava S: A National Cancer Institute workshop on microsatellite instability for cancer detection and familial predisposition: Development of international criteria for the determination of microsatellite instability in colorectal cancer. Cancer Res 58: 5248-5257, 1998.

37 Buhard O, Cattaneo F, Wong YF, Yim SF, Friedman E, Flejou JF, Duval A and Hamelin R: Multipopulation analysis of polymorphisms in five mononucleotide repeats used to determine the microsatellite instability status of human tumors. J Clin Oncol 24: 241-251, 2006.

38 Soreide K: High-fidelity of five quasimonomorphic mononucleotide repeats to high-frequency microsatellite instability distribution in early-stage adenocarcinoma of the colon. Anticancer Res 31: 967-971, 2011.

39 Salvucci M, Lemoine A, Azoulay D, Sebagh M, Bismuth H, Reyns M, May E and Debuire B: Frequent microsatellite instability in post hepatitis B viral cirrhosis. Oncogene 13: 26812685, 1996.

40 Suraweera N, Duval A, Reperant M, Vaury C, Furlan D, Leroy K, Seruca R, Iacopetta B and Hamelin R: Evaluation of tumor microsatellite instability using five quasimonomorphic mononucleotide repeats and pentaplex PCR. Gastroenterology 123: 1804-1811, 2002.
41 Foucault F, Praz F, Jaulin C and Amor-Gueret M: Experimental limits of PCR analysis of (CA)n repeat alterations. Trends Genet 12: 450-452, 1996.

42 Jacob S, Aguado M, Fallik D and Praz F: The role of the DNA mismatch repair system in the cytotoxicity of the topoisomerase inhibitors camptothecin and etoposide to human colorectal cancer cells. Cancer Res 61: 6555-6562, 2001.

43 Fallik D, Borrini F, Boige V, Viguier J, Jacob S, Miquel C, Sabourin JC, Ducreux M and Praz F: Microsatellite instability is a predictive factor of the tumor response to irinotecan in patients with advanced colorectal cancer. Cancer Res 63: 57385744, 2003.

44 Mongiat-Artus P, Miquel C, Van der Aa M, Buhard O, Hamelin R, Soliman H, Bangma C, Janin A, Teillac P, van der Kwast T and Praz F: Microsatellite instability and mutation analysis of candidate genes in urothelial cell carcinomas of upper urinary tract. Oncogene 25: 2113-2118, 2006.

45 Miquel C, Jacob S, Grandjouan S, Aime A, Viguier J, Sabourin JC, Sarasin A, Duval A and Praz F: Frequent alteration of DNA damage signalling and repair pathways in human colorectal cancers with microsatellite instability. Oncogene 26: 5919-5926, 2007.

46 Zaanan A, Cuilliere-Dartigues P, Guilloux A, Parc Y, Louvet C, de Gramont A, Tiret E, Dumont S, Gayet B, Validire P, Flejou JF, Duval A and Praz F: Impact of p53 expression and microsatellite instability on stage III colon cancer disease-free survival in patients treated by 5 -fluorouracil and leucovorin with or without oxaliplatin. Ann Oncol 21: 772-780, 2010.

47 Zaanan A, Flejou JF, Emile JF, des Guetz G, Cuilliere-Dartigues P, Malka D, Lecaille C, Validire P, Louvet C, Rougier P, de Gramont A, Bonnetain F, Praz F and Taieb J: Defective mismatch repair status as a prognostic biomarker of disease-free survival in stage III colon cancer patients treated with adjuvant FOLFOX chemotherapy. Clin Cancer Res 17: 7470-7478, 2011.

48 Sesti F, Tsitsilonis OE, Kotsinas A and Trougakos IP: Oxidative stress-mediated biomolecular damage and inflammation in tumorigenesis. In Vivo 26: 395-402, 2012.

49 Li F, Mao G, Tong D, Huang J, Gu L, Yang W and Li GM: The histone mark H3K36me3 regulates human DNA mismatch repair through its interaction with mutSalpha. Cell 153: 590-600, 2013.

50 Eberle CA, Zayas M, Stukalov A, Pichlmair A, Alvisi G, Muller AC, Bennett KL, Bartenschlager R and Superti-Furga G: The lysine methyltransferase SMYD3 interacts with hepatitis $C$ virus NS5a and is a negative regulator of viral particle production. Virology 462-463: 34-41, 2014.

Received June 19, 2017

Revised July 7, 2017

Accepted July 12, 2017 